\title{
Preferred Learning Styles of Technical- Vocational and Livelihood (TVL) Students in Public Senior High School in Sta. Rosa, Laguna
}

\author{
Jackie D. Urrutia, Irish Jade R. Constantino, Nancy F. Sabordo, Judy H. Verzo
}

\begin{abstract}
This research intends to seek understanding on the learning preferences of the TVL senior high school students. Results showed that most of the respondents are visual when asked how they use their physical senses. When they are asked how they expose themselves to learning situations, they are introvert, concrete sequential when questioned about how they handle possibilities, closure oriented when dealing with ambiguity and deadlines, particular when receiving information, synthesizing when asked on how they further process information, sharpener when grouped according to how they further process information, deductive when asked how they deal with language rules, field- independent when rated on how they deal with multiple inputs, reflective when they were asked how they deal with response time and literal when they were asked how they deal with response time

The results will be an effective tool to maximize their potentials and help them cope with the challenge brought about the individual differences and their unique talents. Also, the result will be a useful feedback to teachers to tailor-fit their teaching styles and competencies to cope with students varied needs. The school and the Department of Education should also take into consideration the result of this study in revisiting and revising the curriculum to meets the needs and demands of the 21st century clients.
\end{abstract}

Index terms: Technical- Vocational and Livelihood (TVL), Learning Styles, Descriptive Study, Senior High Student, Sta. Rosa Laguna

\section{INTRODUCTION}

In an article published by the Education research newsletter and webinars (ernweb) last March 18, 2018, states the importance of understanding different learning styles as regard to the teaching and learning process.

Learning differences, as mentioned by Robert Sternberg are not due solely to differences in ability. Learning styles are directly related to how students achieve in school. He states that most people are flexible in their use of different learning styles and can adapt with varying degrees of success to

Revised Version Manuscript Received on 10, September 2019.

Jackie D. Urrutia, Professor, College of Education-Graduate School, Polytechnic University of the Philippines, Sta. Mesa, Manila, Philippines. Email: jackieurrutia20@gmail.com / jdurrutia@pup.edu.ph

Irish Jade R. Constantino, Teacher II, Aplaya National High School, Sta. Rosa Laguna, Philippines. Email: irishjade.constantino@deped.gov.ph

Jackie D. Urrutia, Teacher III, Judge Feliciano Belmonte Sr. High School, Quezon City, Philippines. Email: nancygrace28@ gmail.com

Irish Jade R. Constantino, Teacher I, Balibago Integrated High School, Sta. Rosa Laguna, Philippines. Email: judyverzo@gmail.com different learning situations. [1]

By the year 2013, the Department of Education in the Philippines implemented its biggest reform in education through the Republic Act No. 10533, otherwise known as the "Enhanced Basic Education Act 0f 2013" From the previous ten-year basic education, it added up another two more years in the learning experience of the students. And so, on 2013, the first senior high school of the Republic of the Philippines was pioneered. One of its salient features was to provide specialized upper secondary education. The program aimed to prepare students for college, job or business and in so doing; allows students to get a glance on the area they want to pursue in the latter years of their life.

Learners will have to undergo assessment in order to determine their strengths and interests. This assessment will then help them decide what specialization to take. One of the specializations under the senior high school program is the Technical- Vocational and Livelihood track wherein students can accomplish Certificates of Competency or National Certificates Level I and II. This aims to prepare them for chances of employment to middle-level skills or entrepreneurs after graduation. Secondary schools offering technical vocational and livelihood track are now challenged by the idea of crafting teaching strategies and method to cater the need of preparing these students for job.

In an article published online about the DepEd- CEAP Mindanao Summit organized by CEAP's National Basic Education Commission and co-hosted by Ateneo de Davao University, an issue had arise during the said forum on the implementation of the TVL Track. According to Fr. Onofre Inocensio of Don Bosco Schools "the senior high school core curriculum requirement are so heavy that there would be no time to develop hands on skills in the students that such as the manufacturing industry requires".[2] Moreover, it won't be possible to fully equip a student to be ready for employment with all the technicalities and dept within a span of two years given that a student shall be required to have 31 subjects (combined core and specialized subjects) given that every subjects shall require an 80 hours per semester of actual classroom contact. Very minimal time will be allotted for hands on activities and very little time to master required skills for employment. 


\section{PREFERRED LEARNING STYLES OF TECHNICAL- VOCATIONAL AND LIVELIHOOD (TVL) STUDENTS IN PUBLIC SENIOR HIGH SCHOOL IN STA. ROSA, LAGUNA}

Added to this problem is the stigma in selecting tech-voc as this is seen by many as the course for poor performing and/ or problematic students [3] Orale, 2016). In this dilemma, a teacher's role will have an incredible effect on the learning process and thus it is important to analyze what the classroom manager should use to facilitate learning effectively in order to inculcate the Vision, Mision and Goal of the Department of Education for them. As for Stensmo (2008): “As the students have to find their best way of working and learning, teachers must find their best way to teach and lead in the classroom and other educational places" (p. 130) [4].

One of the many factors helpful in determining future success of students is understanding the learning styles of the learners in order to help them individually or collectively. A lot of studies were conducted in order to analyze the learning styles. One of those studies considered learning styles as the basis to academic performance [5] (Cox, 2013; Lockie, Lanen \& Mc Gannon, 2013; These studies have proven the positive effect of learning styles to academic performance.

Just as Fr. Joel Tabora, S.J., President of Ateneo de Davao University mentioned in his article, "putting together curricular requirements for the K-12 reform is one thing. Teaching them is quiet another. A curriculum is like a wish list, but all the components of curricula need real teachers." [6]

At the end of the day, teachers are the real heroes in honing and training students for life. That is why; there is a greater need for teachers to determine what better strategies to implement in the day to day class hours to enable the accomplishment of the institutional objectives- which is preparing senior high students to job, business and college.

\section{REVIEW OF RELATED LITERATURE}

Learning is an activity of one who needs to acquire knowledge. It may be intentional or at random; it may involve acquiring new information, new attitudes and understanding of values. It is usually accompanied by a change in behaviour and goes on throughout life. It is often thought of as both can then be defined as the organized, systematic effort to foster learning, to establish conditions and to provide the activities through which learning can occur. [7]

According to Felder \& Brent, learning styles are cognitive, affective and psychological behaviors that serve as relatively stable indicators of how learners perceive, interact with and respond to the learning environment. [8] Cassidy mentioned that learning styles are internally based on characteristics of individuals for intake of understanding of new information. All learners have individual attributes related to the learning processes. Some people may rely on visual presentations; others prefer spoken languages; still others may respond better to hands-on activities. [9]

As stated by Linda Wong on page 5 of her book, Essential Study Skills, 7th Edition, the three types of learners are visual, auditory and kinesthetic. Visual learners learn best by seeing information because they have strong visualization skills and can easily recall information in the form of numbers, words, pictures, charts and diagrams. They also pay close attention and learn to interpret body language. Auditory processes and outcomes. As mentioned by Gross, education

learners are known by gaining information through hearing and by having "finely tuned ears" - they can accurately remember details of information heard on conversations or lectures and they also have strong language skills that include well-developed vocabularies and appreciation of words. Kinesthetic learners learn by using their hands ("hands-on learning) or by full body movement; they also learn well in activities that involve performing. [10]

Muhundan, cited that the need for studying learning styles was highlighted as the need for a comfortable learning environment which will result in effective and efficient knowledge acquisition. When a student is comfortable in learning and acquiring knowledge, undoubtedly effective learning will take place. Comfort level can be acquired by ensuring that a student is in an environment that offers no threats. [11]

Denig stated that the Dunns believed that people are not necessarily intelligent because they have a potential, talent, or innate ability. Rather, people can demonstrate intelligence because of the manner in which they perceive, comprehend, adapt to new situations, learn from experience, seize the essential factors of a complex matter, demonstrate mastery over complexity, solve problems, critically analyze and make productive decisions. Thus, learning becomes a lifelong journey when learning styles are recognized and accounted for. [12]

According to Coffield, et.al, knowledge of an individual's learning style allows complementary teaching resources, materials and techniques to be used appropriately. In over three decades, researchers established a logical principle: the more closely a student is taught in congruence with his/her learning style, the greater that learning and retention of what he learns. [13]

The importance of learning styles is not only necessary, but plays an important part for individuals in academic settings. Often, one's learning styles is identified to determine strengths for academic achievement. Abidin, et.al identified that students retain $10 \%$ of what they read, $26 \%$ of what they hear, $30 \%$ of what they see, $50 \%$ of what they see and hear, $70 \%$ of what they say, and $90 \%$ of what they say as they do something. These facts reveal that each learning style has its own strengths and weaknesses. Some students learn in many ways, while others might only favour one or two. Abidin, et.al further cited that those students with multiple learning styles tend to gain more and obtain higher scores compared to those who rely solely on one style. Additionally, the differences in learning styles have also been reported between gifted and the underachievers, between the learning disabled and average achievers; among different types of special education students; and among secondary students in comprehensive schools and their counterparts in vocational education and industrial arts. Some special students favor kinesthetic instruction, such as experiential, active and hands-on, while many others are more auditory and visually oriented. [14]

Published By: 
Successful learning requires students to interact closely with teachers and peers. Steedly, et.al believed that "social skills are not the same thing as behaviour, rather a set of competencies that allow an individual to initiate and maintain positive social relationships; contribute to peer acceptance and to a satisfactory school adjustment; and allow an individual to cope effectively with the social environment." [15]

Akey asserted that teachers and school-based administrators alike have searched to find ways to increase student achievement in schools. Several widely known and discussed strategies include using data to drive instruction, employing highly qualified teachers, and improving school leadership. Additionally, positive student engagement in the classroom is another compelling factor. Engaged students also are more likely to perform well academically. Thus, teachers are key players in fostering student engagement. They work directly with the students and typically as the most influential in a student's educational experience. Creating a culture of achievement on their classroom, developing interactive and relevant lessons and activities, and being encouraging and supportive to students are all ways in which teachers can foster student engagement in the classroom. [16]

\section{RESEARCH PARADIGM}

The research paradigm of this study is to give a view of the work to be done. As shown in Figure 1 below, the inputs are the demographic profile and the different learning styles such as visual, auditory, tactile/ kinesthetic, extroverted, introverted, random intuitive, concrete-sequential, closure-oriented, open-oriented, global, particular, synthesizing, analytic, sharpener leveler, deductive, inductive, field-independent, field-dependent, impulsive, reflective, metaphoric and literal. The process is the strategy use in this research and that is through the use of survey questionnaire and the output shows the preferred learning styles of the technical-vocational and livelihood senior high school students.

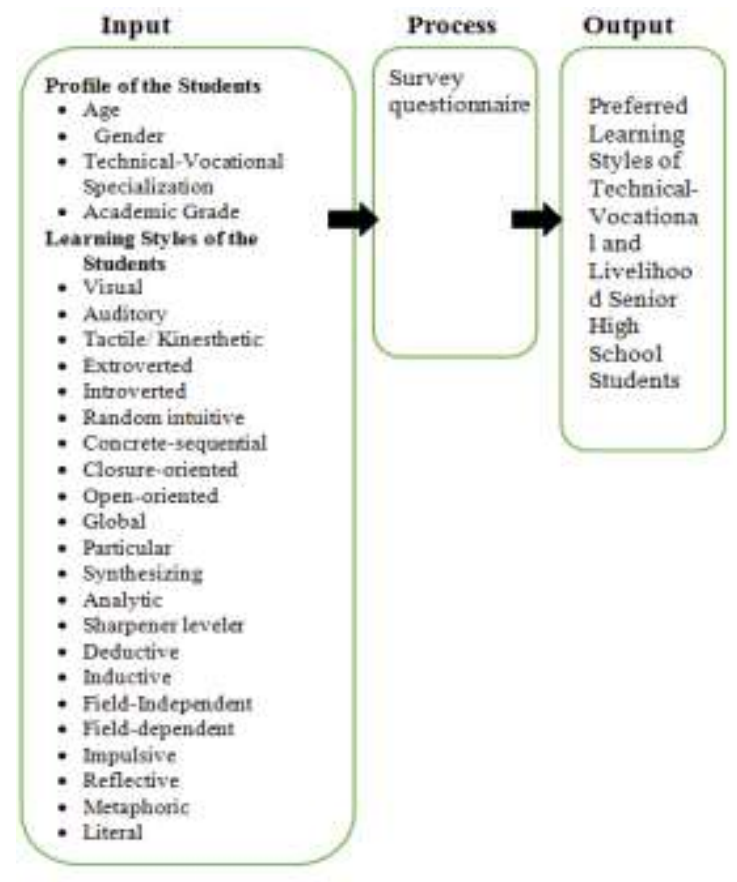

Fig. 1. Research Paradigm

\section{A. Objectives of the Study}

The study assesses the preferred learning styles of technical vocational and livelihood senior high school students in the division of Sta. Rosa City, Laguna. Specifically, it investigated the demographic profile of the respondents in terms of age, gender, technical vocational and livelihood specialization, and academic grade. It also discovered which learning styles are preferred by technical vocational and livelihood students.

\section{B. Scope and Limitation}

This study was conducted to the Technical-Vocational and Livelihood public senior high school students in the division of Sta. Rosa, Laguna. Its focus is to examine the learning styles preferred by these students.

\section{Materials and Methods}

This study employed a descriptive research design. According to Calderon and Gonzales, descriptive research maybe defined as a purposive process of gathering, analyzing, classifying and tabulating data about prevailing conditions, practices, beliefs, processes, trends and cause effect relationships and then making adequate and accurate interpretation about such data with or without the aid of statistical methods. This method were used to determine the preferred learning styles of the students. [17]

\section{Respondents of the Study}

The respondents of the study were 261 technical vocational and livelihood students in public senior high in the City Schools Division of Sta. Rosa, Laguna. For the sampling, Cochran sampling formula was applied in the selection of the respondents. All data gathered in this study are obtained from the TVL- Senior High School students from the Division of Sta. Rosa City, Laguna. The total population size is 820. As shown below, Cochran formula was used to determine the total sample size and was able to arrive at a number of respondents as shown in Table I which results to 261 .

$$
n=\frac{n_{0}}{1+\frac{\left(n_{0}-1\right)}{N}}
$$

In which $\mathrm{n}$ is the size of the sample, $\mathrm{N}$ is the size of the population and e is the margin of error which is $5 \%$ or 0.05 .

Applying the formula, the computation of the sample size is shown below:

$$
\begin{aligned}
& n=\frac{n_{0}}{1+\frac{\left(n_{0}-1\right)}{N}} \\
& n=\frac{384}{1+\frac{(384-1)}{820}}
\end{aligned}
$$




$$
\begin{gathered}
n=\frac{384}{1+\frac{383}{820}} \\
n=\frac{384}{1+0.47}=261.22 \text { or } 261
\end{gathered}
$$

Table I: Distribution of the Respondents

\begin{tabular}{lcccc}
\hline \hline \multicolumn{1}{c}{ Name of School } & $\begin{array}{c}\text { Population } \\
\text { Frame }\end{array}$ & $\begin{array}{c}\text { Sample } \\
\text { Scheme }\end{array}$ & $\begin{array}{c}\text { Population } \\
\text { Frame }\end{array}$ & $\begin{array}{c}\text { Sample } \\
\text { Scheme }\end{array}$ \\
\hline & Grade 11 & & Grade 12 \\
Aplaya National High School & 63 & 20 & 54 & 17 \\
Balibago National High School & 112 & 36 & 77 & 25 \\
Don Jose National High School & 71 & 23 & 58 & 18 \\
Santo Domingo National High School & 118 & 38 & 110 & 35 \\
Sinalhan Senior High School & 90 & 29 & 67 & 21 \\
Total No. of TVL Students & 454 & 146 & 366 & 115 \\
\hline \hline
\end{tabular}

\section{E. Research Instrument and Data Collection}

A standardized questionnaire developed by Andrew D. Cohen, Rebecca L. Oxford, and Julie C. Chi (Mikk e al., 2009) was utilized with permission from the Center of Advanced Research and Language Acquisition (CARLA) at the University of Minnesota.

Table II: Table of Specification for Learning Styles

\begin{tabular}{ll}
\hline \multicolumn{1}{c}{ Learning Styles } & \multicolumn{1}{c}{ Item Placement } \\
\hline Visual & $1,4,7,10,13,16,19,22,25,28$ \\
Auditory & $2,5,8,11,14,17,20,23,26,29$ \\
Kinaesthetic & $3,6,9,12,15,18,21,24,27,30$ \\
Extroverted & $1,3,5,7,9,11$ \\
Introverted & $2,4,6,8,10,12$ \\
Random-Intuitive & $1,3,5,7,9,11$ \\
Concrete-Sequential & $2,4,6,8,10,12$ \\
Closure-Oriented & $1,3,5,7$ \\
Open & $2,4,6,8$ \\
Global & $1,3,5,7,9$ \\
Particular & $2,4,6,8,10$ \\
Synthesizing & $1,3,5,7,9$ \\
Analytic & $2,4,6,8,10$ \\
Sharpener & $1,3,5$ \\
Leveler & $2,4,6$ \\
Deductive & $1,3,5$ \\
Inductive & $2,4,6$ \\
Field-Independent & $1,3,5$ \\
Field-Dependent & $2,4,6$ \\
Impulsive & $1,3,5$ \\
Reflective & $2,4,6$ \\
Metaphoric & 1,3 \\
Literal & 2,4 \\
\hline \hline
\end{tabular}

Table III: Numeric Rating and Verbal Interpretation for Learning Styles

\begin{tabular}{cc}
\hline \hline Numeric Rating & Verbal Interpretation \\
\hline 4 & Always \\
3 & Often \\
2 & Sometimes \\
1 & Rarely \\
0 & Never \\
\hline \hline
\end{tabular}

The table II shows the table of specification with the item placement for each different learning styles and table III shows the numeric rating and verbal interpretation for learning styles. It was formulated from the standardized questionnaire developed by Andrew D. Cohen, Rebecca L. Oxford, and Julie C. Chi (Mikk et al., 2009). Upon the successful retrieval of the questionnaire, data were organized and tallied systematically. Descriptive statistics were mainly frequency count and percentages were used by employing SPSS computer software in the presentation, analysis and interpretation of the findings.To compare the respondents' response derived from the questionnaire, the statistical formula used was the frequency count and percentage. It is calculated through the following formula:

$$
\mathrm{p}=\frac{\mathrm{f}}{\mathrm{n}} \mathrm{x} 100
$$

Where: $\mathrm{P}$ is the percentage

$\mathrm{f}$ is the frequency

$\mathrm{n}$ is the number of cases

\section{RESULTS AND DISCUSSION}

The study was conducted to assess the preferred learning styles of TVL students in the Division of Sta. Rosa. While the objective of the study is not to predict a particular behavior, learning style preference is an effective tool for students to attain academic success. Also, the result of this study is useful for teachers and other academicians to help students individually and collectively.

Table IV: Frequency and Percentage Distribution of TVL Senior High School Students According to Their

\begin{tabular}{|c|c|c|}
\hline Age & $\begin{array}{c}\text { Frequency } \\
\text { (f) }\end{array}$ & $\begin{array}{c}\text { Percentage } \\
(\%)\end{array}$ \\
\hline 16 years old & 29 & $11.1 \%$ \\
\hline 17 years old & 102 & $39.1 \%$ \\
\hline 18 years old & 82 & $31.4 \%$ \\
\hline 19 years old & 34 & $13.0 \%$ \\
\hline $\begin{array}{l}20 \text { years old and } \\
\text { above }\end{array}$ & 14 & $5.4 \%$ \\
\hline Total & 261 & $100.0 \%$ \\
\hline
\end{tabular}
Age 
Majority of the respondents (39.1\%) were seventeen (17) year of age at the time of the conduct of the study.

Table V: Frequency and Percentage Distribution of Gender

\begin{tabular}{lcc}
\hline \hline Gender & Frequency (f) & Percentage (\%) \\
\hline Male & 130 & $49.8 \%$ \\
Female & 131 & $50.2 \%$ \\
Total & 261 & $100.0 \%$ \\
\hline \hline
\end{tabular}

There were $130(49.8 \%)$ male and $132(50.2 \%)$ female respondents. It is expected that the number of male and female respondents is closely the same since the TVL track offers both specialization suited for male and female.

Table VI: Frequency and Percentage Distribution of TVL Senior High School Students According to Their

\begin{tabular}{lcc}
\hline \hline \multicolumn{1}{c}{$\begin{array}{c}\text { TechVoc } \\
\text { Specialization }\end{array}$} & $\begin{array}{c}\text { Frequency } \\
(\mathbf{f})\end{array}$ & $\begin{array}{c}\text { Percentage } \\
(\mathbf{\%})\end{array}$ \\
\hline Home Economics & 81 & $31.0 \%$ \\
Industrial Arts & 77 & $29.5 \%$ \\
ICT & 103 & $39.5 \%$ \\
Total & 34 & $100.0 \%$ \\
\hline \hline
\end{tabular}

Among the four TVL specializations offered by the said division, most of them took the Information and Communication Technology or ICT which was identified as $39.5 \%$ of the total population.

Table VII: Frequency and Percentage Distribution of TVL Senior High School Students According to Their Grade

\begin{tabular}{lcc}
\hline \hline Age & Frequency (f) & Percentage (\%) \\
\hline $97-100$ & 3 & $1.1 \%$ \\
$94-96$ & 12 & $4.6 \%$ \\
$91-93$ & 32 & $12.3 \%$ \\
$88-90$ & 41 & $15.7 \%$ \\
$85-87$ & 131 & $50.2 \%$ \\
$82-84$ & 25 & $9.6 \%$ \\
$80-81$ & 12 & $4.6 \%$ \\
$78-79$ & 5 & $1.9 \%$ \\
Total & 261 & $100.0 \%$ \\
\hline \hline
\end{tabular}

The greatest population as identified according to their general average on their specialized subject were among those who got the grades between $85-87 \%$ (50.2\%).

Table VIII: Frequency and Percentage Distribution of TVL Senior High School Students Preferred Learning Style According on How they use their physical senses

\begin{tabular}{lccc}
\hline \hline $\begin{array}{c}\text { Learning } \\
\text { Style }\end{array}$ & $\begin{array}{c}\text { Frequency } \\
\text { (f) }\end{array}$ & $\begin{array}{c}\text { Percentage } \\
(\boldsymbol{\%})\end{array}$ & Rank \\
\hline Visual & 113 & $43.3 \%$ & 1 \\
Auditory & 66 & $25.3 \%$ & 2 \\
Kinaesthetic & 35 & $13.4 \%$ & 4 \\
Combination & 47 & $18.0 \%$ & 3 \\
Total & 261 & $100.0 \%$ & \\
\hline \hline
\end{tabular}

Table VIII show that the learning preference of the TVL students is visual rather than auditory and kinesthetic when asked how they use their physical senses which mean that they prefer visual presentations of materials such s diagrams, charts, graphs and pictures (Felder \& Solomon, 2002). This finding is in agreement with the study of D' Cruz and Raja Ratman (2013) and Contreras, Velez and Golem Bienki TVL Senior High School Students According to Their

(2013) who found the same result in their study.

Table IX: Frequency and Percentage Distribution of TVL Senior High School Students According to How they expose themselves to learning situations

\begin{tabular}{lccc}
\hline \hline $\begin{array}{c}\text { Learning } \\
\text { Style }\end{array}$ & $\begin{array}{c}\text { Frequency } \\
(\mathbf{f})\end{array}$ & $\begin{array}{c}\text { Percentage } \\
(\boldsymbol{\%})\end{array}$ & Rank \\
\hline Extroverted & 87 & $33.3 \%$ & 2 \\
Introverted & 134 & $51.3 \%$ & 1 \\
Both & 40 & $15.3 \%$ & 3 \\
Total & 261 & $100 \%$ & \\
\hline \hline
\end{tabular}

With regards the respondents were asked how they expose themselves to learning situations, it came out that most of them are introverts than extrovert which means they prefer to work independently and they prefer to work on tasks alone. Although they can work with other people, students with this kind of preference might tend to choose people they feel comfortable with especially in pairs. They also appear to be reflective or reserved (Carson, 2009, Dunn \& Burks, 2006, Felder, 1996). The result supports the findings of Tudy (2014) who found their respondents to be introverts.

Table X: Frequency and Percentage Distribution of TVL Senior High School Students Preferred Learning Style According to How they handle possibilities

\begin{tabular}{lccc}
\hline \hline Learning Style & $\begin{array}{c}\text { Frequency } \\
\text { (f) }\end{array}$ & $\begin{array}{c}\text { Percentage } \\
(\boldsymbol{\%})\end{array}$ & Rank \\
\hline Random-Intuitive & 112 & $42.9 \%$ & 1 \\
Concrete-Sequential & 88 & $33.7 \%$ & 2 \\
Both & 61 & $23.4 \%$ & 3 \\
Total & 261 & $100 \%$ & \\
\hline \hline
\end{tabular}

This table shows that a general population of TVL students are random- intuitive rather than concrete sequential when questioned about how they handle possibilities. This means that they are more likely to be future oriented, pefer what can be over what is. They also like to be speculative on things and enjoy abstract thinking and tend to tend to disfavor step-by-step instruction. (CARLA Ins.).

Table XI: Frequency and Percentage Distribution of TVL Senior High School Students Preferred Learning Style According to How they deal with ambiguity and with deadlines

\begin{tabular}{llll}
\hline \hline Learning Style & $\begin{array}{l}\text { Frequency } \\
\text { (f) }\end{array}$ & $\begin{array}{l}\text { Percentage } \\
(\%)\end{array}$ & Rank \\
\hline Close Oriented & 142 & $54.4 \%$ & 1 \\
Open Oriented & 60 & $23.0 \%$ & 2 \\
Both & 59 & $22.6 \%$ & 3 \\
Total & 261 & $100.0 \%$ & \\
\hline \hline
\end{tabular}

Table XI depicts a great number of students whose preference on how they deal with ambiguity and deadlines is closure- oriented and a least number is open- oriented. According to the article who authored the learning styles survey, a student who perceived to be closure oriented when dealing with ambiguity and deadlines probably focus 
carefully on most or all learning tasks. They strive to meet deadlines, plan ahead for assignments, and want explicit directions.

Table XII: Frequency and Percentage Distribution of TVL Senior High School Students According to How they receive information

\begin{tabular}{lccc}
\hline \hline \multicolumn{1}{c}{ Learning Style } & $\begin{array}{c}\text { Frequency } \\
(\mathbf{f})\end{array}$ & $\begin{array}{c}\text { Percentage } \\
(\boldsymbol{\%})\end{array}$ & Rank \\
\hline Global & 76 & $29.1 \%$ & 2 \\
Particular & 140 & $53.6 \%$ & 1 \\
Both & 45 & $17.2 \%$ & 3 \\
Total & 261 & $100.0 \%$ & \\
\hline \hline
\end{tabular}

Table XII indicates that most of the respondents appeared to be Particular than Global under that category of Receiving of Information. As mentioned by CARLA students possessing this type of learning preference enjoy getting the gist or main idea and are comfortable communicating even if you don't know all the words or concepts.

Table XIII: Frequency and Percentage Distribution of TVL Senior High School Students According to How they further process information

\begin{tabular}{lccc}
\hline \hline \multicolumn{1}{c}{ Learning Style } & $\begin{array}{c}\text { Frequency } \\
(\mathbf{f})\end{array}$ & $\begin{array}{c}\text { Percentage } \\
(\boldsymbol{\%})\end{array}$ & Rank \\
\hline Synthesizing & 120 & $46.0 \%$ & 1 \\
Analytic & 95 & $36.4 \%$ & 2 \\
Both & 46 & $17.6 \%$ & 3 \\
Total & 261 & $100.0 \%$ & \\
\hline \hline
\end{tabular}

Table XIII details a big percentage of students whose preference is synthesizing rather than analyzing when asked according to how they further process information. In the same article, it was mentioned that learners with this preference can summarize material well, enjoy guessing meanings and predicting outcomes, and notice similarities quickly.

Table XIV: Frequency and Percentage Distribution of TVL Senior High School Students According to How they commit material to memory

\begin{tabular}{llll}
\hline \hline Learning Style & $\begin{array}{l}\text { Frequency } \\
\text { (f) }\end{array}$ & $\begin{array}{l}\text { Percentage } \\
(\%)\end{array}$ & Rank \\
\hline Sharpener & 122 & $46.7 \%$ & 1 \\
Leveler & 67 & $25.7 \%$ & 3 \\
Both & 72 & $27.6 \%$ & 2 \\
Total & 261 & $100.0 \%$ & \\
\hline \hline
\end{tabular}

Table XIV reveals that most of the TVL students in the Division happened to be sharpener and least of them are Leveler when they are grouped according to how they further process information. It was mentioned by CARLA Inst. that students having this kind or preference tend to notice differences and seek distinctions among items as you commit material to memory. They like to distinguish small differences and separate memories of prior experiences from memories of current ones. These type of students can easily retrieve the different items because they store them separately. They like to make fine distinctions among speech sounds, grammatical forms, and meaningful elements of language (words and phrases).
Table XV: Frequency and Percentage Distribution of TVL Senior High School Students According to How they deal with language rules

\begin{tabular}{cccc}
\hline \hline Learning Style & $\begin{array}{c}\text { Frequency } \\
(\mathbf{f})\end{array}$ & $\begin{array}{c}\text { Percentage } \\
(\boldsymbol{\%})\end{array}$ & Rank \\
\hline Deductive & 115 & $44.1 \%$ & 1 \\
Inductive & 78 & $29.9 \%$ & 2 \\
Both & 68 & $26.1 \%$ & 3 \\
Total & 261 & $100.0 \%$ & \\
\hline \hline
\end{tabular}

Table XV shows that most of the respondents are deductive than inductive when asked how to deal with language rules. As described by the Learning styles Survey, students that fall under this category go from general to the specific, to apply generalizations to experience, and to start with rules and theories rather than with specific examples.

Table XVI: Frequency and Percentage Distribution of TVL Senior High School Students According to How they deal with multiple inputs

\begin{tabular}{lccc}
\hline \hline Learning Style & $\begin{array}{c}\text { Frequency } \\
(\mathbf{f})\end{array}$ & $\begin{array}{c}\text { Percentage } \\
(\boldsymbol{\%})\end{array}$ & Rank \\
\hline Field-independent & 93 & $35.6 \%$ & 2 \\
Field-dependent & 95 & $36.4 \%$ & 1 \\
Both & 73 & $28.0 \%$ & 3 \\
Total & 261 & $100 \%$ & \\
\hline \hline
\end{tabular}

Table XVI states that a big number of TVL students lean towards being field- dependent than being field- independent when rated on how they deal with multiple inputs. In the same way, it was analyzed that having this kind of preference means they like to separate or abstract material from within a given context, even in the presence of distractions. They may, however, have less facility dealing with information holistically.

Table XVII: Frequency and Percentage Distribution of TVL Senior High School Students According to How they deal with response time

\begin{tabular}{lccc}
\hline \hline \multicolumn{1}{c}{ Learning Style } & $\begin{array}{c}\text { Frequency } \\
(\mathbf{f})\end{array}$ & $\begin{array}{c}\text { Percentage } \\
(\mathbf{\%})\end{array}$ & Rank \\
\hline Impulsive & 74 & $28.4 \%$ & 3 \\
Reflective & 111 & $42.5 \%$ & 1 \\
Both & 76 & $29.1 \%$ & 2 \\
Total & 261 & $100 \%$ & \\
\hline \hline
\end{tabular}

Table VII summarizes that the students are more reflective than impulsive when they were asked how they deal with response time which means they think things through before taking action and often do not trust their gut reactions. In this case, action usually follows thought (CARLA). 
Table XVIII: Frequency and Percentage Distribution of TVL Senior High School Students According to How they literally take reality

\begin{tabular}{lccc}
\hline \hline \multicolumn{1}{c}{ Learning Style } & $\begin{array}{c}\text { Frequency } \\
(\mathbf{f})\end{array}$ & $\begin{array}{c}\text { Percentage } \\
(\boldsymbol{\%})\end{array}$ & Rank \\
\hline Metaphoric & 84 & $32.2 \%$ & 2 \\
Literal & 96 & $36.8 \%$ & 1 \\
Both & 81 & $31.0 \%$ & 3 \\
Total & 261 & $100 \%$ & \\
\hline \hline
\end{tabular}

This table described the majority of the TVL students that falls under Literal rather than Metaphoric when asked as to how they literally take reality. CARLA described these types of students as the group who enjoy getting the gist or main idea and are comfortable communicating even if they don't know all the words or concepts.

\section{CONCLUSION AND RECOMMENDATION}

This assessment to learning style is highly beneficial since the main focus of this study is the improvement of learning outcomes. On the part of the teacher, it will be an effective feedback on knowing students in a deeper level (Evans and Waring, 2006) and in so doing could adjust their teaching styles to suit individual needs. [18]

Furthermore, teachers should also take into consideration applying variety of strategies even if some has their own preferred learning style [19]. As what Hall and Mosley, Honigsfeld and Scheiring (2004); Sternberg et al., (2008) said, "When teachers have a better understanding on students learning styles, there is a high degree of effectiveness on instruction and assessment" [20] [21].

Based on the study conducted, the researchers would like recommended the following techniques for instruction: For students who perceived to be visual learners as grouped as to how they use their physical senses, visual representations such as diagrams, charts, graphs and pictures will be a better tool to aid instruction (Felder \& Solomon, 2002). [22] Long lectures, conversations and oral directions without any visual back up can be very confusing (Oxford, 2003). [23]

Introverts prefer to work independently. They like to study or read by themselves. They can learn with a company or partnered task would also be beneficial to them but only to those they like working to. Tanner Higgin (2017) suggested building a quiet time into the school day by having fifteen (15) minute- set aside time every day for just reading time. In the same article, he also added to reform recess by letting students to sit and play board games in small groups, or by just hanging out and chill. An article from Ideas.ted.com suggested using the Think- Pair- Share strategy by allowing students to sit by themselves for a minute and pair up and discuss together an idea that was given by the instructor and let them share. Also, the use of technology tools allows students to participate through electronic device as opposed to raising their hands. Another technique shared by the same article is the use of class online blogging to address collaboration including students having introvert personalities and has reflective preference under the category of dealing with response time in order to break psychological barrier in participation. [24]

The Department of Education, on its advocacy of reforming the system by implementing the k12 curriculum adopted a strategy of localization, indigenization and contextualization of curriculum. An article from blogpost.com by Pecson (2014) describes localization as the process of adapting and relating the content of the curriculum and the process of teaching and learning to local condition, environment and resources. Meanwhile, he defined contextualization as the process of presenting lesson in meaningful and relevant context based on previous experiences and real-life situations. This idea addresses what the learners need especially amongst students who perceived to be random intuitive, particular, sharpener, field- dependent and literal. [25]

For TVL students whose learning styles are synthesizer and deductive, the researchers recommend that educators may use variety of teaching styles such as mind mapping. A teacher can also lay down the concept of the lesson to be taught with what was learned yesterday for the discussion today. In this way, students will find it easy to understand the connection of the new lesson to the entirety of the course. In this manner, students whose preference is particular according to how they receive information and field- dependent according to how they deal with multiple inputs will grasp the knowledge in a more meaningful way (Cox, 2012). [26]

Teachers who present examples and let students explain their thinking, let them generate their own examples afterwards addresses the need of those students that are synthesizer. Added to this is establishing a connection of the lesson to the course description and bringing the activity to closure.

Personalizing learning aligns with the idea that education should not be a one-size fits all model (Amanda Morin). But we should not limit them on the preference they find easy. Instead, allow them to expose themselves to their least preferred style in order to develop them holistically and help them adjust to the real world when they go out of education. [27] Even before planning suitable teaching design, teachers must consider the learning styles of the students (O’Leary \& Stewart (2013). [28] Similarly, teachers are encouraged to employ different teaching techniques (Bostrom \& Hallin, 2013) to cater to differences among the varied learning styles.[29] Then, If teachers use teaching strategies suited to the learning styles of the learners, the latter will improve in their academic performance. [30]

\section{REFERENCES}

1. Robert Sternberg, The Importance of Understanding Individual Learning Styles, URL: https://www.ernweb.com/educational-research-articles/th e-importance-of-understanding-individual-learning-styles /, date retrieved: March 18, 2018

2. Onofre, Serious Problems with the K-12 Senior High School Curriculum, URL: https://taborasj.wordpress.com/2014/02/18/serious-probl ems-with-the-k-12-senior-high-school-curriculum/, date retrieved: February 18, 2014 

PUBLIC SENIOR HIGH SCHOOL IN STA. ROSA, LAGUNA

3. Orale, 2016, Senior High School Curriculum in the Philippines, USA and Japan, Research gate, pp.16

4. Stensmo, 2006, Perceptual Reference In Learning Among Teacher Education Students in Practical Aesthetical Subjects, paper presented at the NFPF conference

5. Cox, T. D. (2013). Learning Styles and Admission Criteria as Predictors of Academic Performance of College Freshmen. Institute for Learning Styles Journal, 1(1). URL:

http://www.auburn.edu/academic/education/ilsrj/Journal \%20Volumes/Spring\%202013\%20Vol\%201\%20PDFs/L earning $\% 20$ Styles $\% 20$ and $\% 2$

Admission \%20Criteria\%20as\%20Predictors $\% 20$ of $\% 20 \mathrm{~A}$ cademic\%20Performance.pd, date retrieved: November 15,2013

6. Joel Tabora, Serious Problems With The K-12 Senior High School Curriculum, URL: https://taborasj.wordpress.com/2014/02/18/serious-probl ems-with-the-k-12-senior-high-school-curriculum/, date retrieved: February 18, 2014

7. Gross, Ronald. 2004. Peak Learning. USA. Library of Congress

8. Felder \& Brent. (2005). Understanding Student Differences URL:

www.4.ncsu.edu/unity/locker/users/Felder/public/Papers/ Understanding

9. Cassidy (2004). Learning Styles and High School Students' Chemistry Achievement. Science Education International Vol. 18, No. 1,

10. Wong, Linda (2012), Essential Study Skills, 7th Edition

11. Muhundan (2011). Matching Learning Styles and Teaching Styles in Biology Teaching: An Alternative Approach to Mainstream Science Education in Singapore. URL: http://www.math.nus.edu.sg/aslaksen/projects/Vanessa.p df

12. Denig, Stephen J. (2004). Multiple Intelligences and Learning Styles: Two Complimentary Dimensions URL: http://projects.cbe.ab.ca.central/altidul/FILES

13. Coffield, et.al (2004). Learning styles and pedagogy in post-16 learning A systematic and critical review. URL: http://www.leerbeleving.nl/wp-content/uploads/2011/09/ learning-styles.pdf

14. Abidin, et.al (2011). Learning Styles and Overall Academic Achievement in a Specific Educational System. International Journal of Humanities and Social Science Vol. 1, no. 10, August 2011.

15. Steedly (2008). Social Skills and Academic Achievement. Evidence for Education, Volume III, Issue 2. URL: http://www.parentcenterhub.org/repository/social-skills/

16. Akey, T.M (2006). School Context, student attitudes and behaviors, and academic achievement: An Exploratory analysis. New York: MDRC. URL: http://www.mdrc.org/publications/419/full.pdf

17. Methods of Research and Thesis Writing, p. 62 reprint 2017

18. Evans, C. \& Waring, M. (2006). Towards teacher inclusive education:Sensitising individuals to how they learn. Educational Psychology, 26(4),499-518).

19. Crawford, S., Alhreish, S., and Popovich, N. (2012). Comparison of learning styles of Pharmacy students and faculty members. American Journal of Pharmaceutical Education, 76 (10) 1-6.

20. Hall, E. \& Moseley, D. (2005). Is there a role of learning styles in personalized education and training? International Journal of Lifelong Education, 24(3), 243-255. URL: http://dx.doi.org/10.1080/02601370500134933.

21. Sternberg, R., Grigorenko, E. and Zhang, L. (2008). Styles of learning and thinking matter in instruction and assessment. Perspective of Psychological Science, 3(6), 486-506. http://dx.doi.org/10.1111/j.1745-6924.2008.00095.x
22. Felder and Solomon, B. 2002, Learning Styles and Strategies, journal of educational psychology, 107

23. Oxford, Rebecca L. , 2003, Language stykes and strategies: an overview, GALA, 3-4

24. Higgin, Tanner, 5 classroom strategies that help introverts and extroverts do their best work, URL: https://www.commonsense.org/education/blog/5-classroo $\mathrm{m}$-strategies-that-help-introverts-and-extroverts-do-theirbest-work

25. Ryan Pecson, Localization and Contextualization in Teaching K-12 Social Studies URL: http://ryanramoletepecson.blogspot.com/2014/06/localiz ation-and-contextualization-in.html

26. Janelle cox, teaching Strategies to Approach Different Learning Styles, URL: http://www.teachhub.com/teaching-strategies-approach-d ifferent-learning-styles

27. Amanda Morin, Personalized Learning: What You Need to Know, URL: https://www.understood.org/en/school-learning/partnerin g-with-childs-school/instructional-strategies/personalized -learning-what-you-need-to-know

28. O'Leary, C., \& Stewart, J. (2013). The Interaction of Learning Styles and Teaching Methodologies in Accounting Ethical Instruction. Journal of business ethics, 1-17. URL: http://link.springer.com/article/10.1007/s10551-012-129 1-9, date retrieved January 31, 2014

29. Bostrom, L., \& Hallin, K. (2013). Learning Style Differences between Nursing and Teaching Students in Sweden: A Comparative Study. International Journal of Higher Education, 2(1), p22. URL: http://sciedu.ca/journal/index.php/ijhe/article/view/2264, date retrieved January 31, 2014

30. Prabha, V., Geetha, K. B., Doddamani, B. R., Prakash, M., \& Prakash, S. M. (2013). Learning styles among the first year medical students. Int J Pharm, 4(2), 135-139. URL: http://www.

pharmscidirect.com/Docs/IJPBR-2013-02-154.pdf, date retrieved: January 10, 2014 